\title{
Zinc induced leucocyte anomalies in the fresh water teleost Clarias batrachus
} V. K. Verma ${ }^{1}$, *Neelima Gupta ${ }^{2}$ and D. K. Gupta ${ }^{3}$

\author{
${ }^{1}$ Department of Environmental Science, \\ Future Institute of Engineering and Technology, \\ BAREILLY(INDIA) \\ ${ }^{2}$ C.S.J.M. University \\ KANPUR (INDIA) \\ ${ }^{3}$ Department of Zoology, \\ Bareilly College, BAREILLY(INDIA) \\ *Corresponding Author \\ E-mail : guptagrawal@rediffmail.com
}

Received : 25.03.2020; Accepted : 22.04.2020

\begin{abstract}
Changes in Differential Leucocyte Count (DLC) were evaluated in the blood of the fish species Clarias batrachus and this was used as an in situ indicator of the species' exposure to zinc.Due to feeding and living in the aquatic environments, fish are particularly vulnerable and are heavily exposed to pollution because they cannot escape from the detrimental effects of pollutants. In the present study, the effects of zinc on the DLC(small and large lymphocytes, neutrophils, monocytes, eosinphils and basophils) were examined under three different concentrations of zinc (1.00 ppm, $3.00 \mathrm{ppm}$ and $6.00 \mathrm{ppm})$ during 7, 14, 21 and 28 days exposure period. During examination, the percentage of both lymphocytes were significantly lower as exposure time and concentration increased while in the case of neurtophils and monocytes, counts, were higher. Eosinophils showed slight increase whereas basophils showed fluctuations in their results. The study of this research infers that the essential metal in undesirable condition can affect the fish health. DLC represents a suitable biomarker of environmental health and provides a tool for biomonitoring water quality.
\end{abstract}

KEY WORDS : C. batrachus, Differential Leucocyte Count, Zinc.

\section{Introduction}

The role of trace elements in biological systems has been described in several animals including fish. They are required for the normal life processes like skeletal formation, maintenance of colloidal systems, regulation of acid-base equilibrium and for biologically important compounds such as hormones and enzymes ${ }^{1}$. Mineral deficiencies can cause biochemical, structural and functional pathologies, which depend on several factors, including the duration and degree of mineral deprivation.Fresh waters are highly vulnerable to pollution since they act as immediate sinks for human activities ${ }^{20}$. Mostly fishes have a tendency to bioaccumulate such type of xenobiotics and humans can be at great risk being at the top of the food chain ${ }^{5}$.

Zinc $(Z n)$ is an essential trace mineral that is required for growth and metabolism of all vertebrates including fish. It is needed in more than 1000 structural, catalytic and regulatory proteins, which are important for growth, development and physiology of animals ${ }^{6,16}$. It may be transported to aquatic ecosystems also due to both, natural and anthropogenic activities ${ }^{23}$. Through polluted water this metal reaches fish body via gills ${ }^{7}$. Several workers have investigated the haematological changes of pollutants on fish ${ }^{19}$. Haematological parameters can be used as indicator of zinc related immune stress in fish exposed to elevated zinc levels ${ }^{14}$. WBC consisting of granulocytes, monocytes, lymphocytes and thrombocytes play a major role in the defense mechanism of the fish. Granulocytes and monocytes function as phagocytes to salvage debris from injured tissues and lypmhocytes produce antibiotics ${ }^{4}$.Zinc may have negative effect in haematological and immune parameters of the fish resulting in disease and even death ${ }^{14,18,21,25,29}$. Immune system gets triggered as a result the WBC leave blood and enter the affected regions which is reflected in the numberof cells ${ }^{24}$.Significant differences in differential leucocyte counts between control and $Z n$ exposed group were observed in Abramisbrama juveniles ${ }^{26}$. The present study was undertaken to evaluate the DLC count resulting from exposure of the fresh water fish,Clarias batrachus to sublethal concentration of zinc in water. 
TABLE-1 :Haematological parameters of $C$. batrachus exposed to various concentration of zinc

\begin{tabular}{|c|c|c|c|c|c|c|c|c|c|c|c|c|c|c|}
\hline \multirow[b]{3}{*}{ No. } & \multirow[t]{3}{*}{ Parameters } & \multirow[t]{3}{*}{$\begin{array}{l}\text { Group A } \\
\text { (Control) }\end{array}$} & \multicolumn{4}{|c|}{$\begin{array}{c}\text { Group B } \\
(1.00 \text { ppm Zn) }\end{array}$} & \multicolumn{4}{|c|}{$\begin{array}{c}\text { Group C } \\
(3.00 \mathrm{ppm} \mathrm{Zn)}\end{array}$} & \multicolumn{4}{|c|}{$\begin{array}{c}\text { Group D } \\
(6.00 \mathrm{ppm} \mathrm{Zn)}\end{array}$} \\
\hline & & & \multicolumn{12}{|c|}{ Days } \\
\hline & & & 7 & 14 & 21 & 28 & 7 & 14 & 21 & 28 & 7 & 14 & 21 & 28 \\
\hline 1. & $\begin{array}{c}\text { Small } \\
\text { Lymphocytes }\end{array}$ & 44 & 41 & 40 & 38 & 37 & 40 & 38 & 38 & 36 & 39 & 37 & 35 & 36 \\
\hline 2 & $\begin{array}{c}\text { Large } \\
\text { Lymphocytes }\end{array}$ & 34 & 32 & 30 & 28 & 26 & 32 & 29 & 27 & 26 & 31 & 29 & 27 & 25 \\
\hline 3 & Neutrophils & 15 & 17 & 20 & 23 & 27 & 19 & 21 & 23 & 26 & 20 & 22 & 23 & 27 \\
\hline 4 & Monocytes & 3 & 5 & 5 & 5 & 6 & 5 & 7 & 6 & 6 & 5 & 6 & 7 & 5 \\
\hline 5 & Eosinophils & 3 & 4 & 4 & 5 & 4 & 3 & 4 & 5 & 5 & 4 & 5 & 6 & 6 \\
\hline 6 & Basophils & 1 & 1 & 1 & 1 & 0 & 1 & 1 & 1 & 1 & 1 & 1 & 2 & 1 \\
\hline
\end{tabular}

\section{Material and Methods}

Clarias batrachus $(n=64)$ were collected from different fish markets of Bareilly district and acclimatized for 7 days to laboratory conditions. Sixteen healthy and large sized fishes (30-80 gms) were selected for each experimental group. One control and 3 toxic levels of zinc ( $\mathrm{Zn})$ were designed for the experiment as detailed below:

Group 'A'-Control.

Group 'B'-Exposed to low concentration (1.0 ppm) of Zn.

Group ' $C$ '-Exposed to intermediate concentration(3.00ppm) of Zn.

Group 'D'-Exposed to high concentration (6.00ppm) of Zn.

Thin blood smears were prepared on clean slides, immediately air-dried and fixed in methanol for 2-5 minutes. The blood films were stained with Giemsa (Qualigens) in phosphate buffer solution ( $\mathrm{pH}$ 6.8). The solutions were mixed uniformly in the ratio $1: 7$, stained for 40 mins, washed throughly in running tap water to wash the excess stain, allowed to dry and mounted in DPX.The cells were counted using high power microscope in a strip running along the whole length of the film by means of manual / electronic blood cell counter. At least 100 cells were counted and the leucocytes differentiated by the morphological characteristics of the nucleus and characterized as small lymphocytes, large lymphocytes, monocytes, neutrophils, eosinophils and basophils ${ }^{27}$.

\section{Results}

Small lymphocytes, large lymphocytes, monocytes, neutrophils, eosinophils and basophils constitute that DLC of $C$. batrachus(Fig.1). In the fishes exposed to zinc, the values of small and large lymphocytes decreased significantly, the maximum decrease in small lymphocytes was 35\% (21 days: Group D) (Graph 1) while the large lymphocytes decreased to $25 \%$ during highest concentration and final exposure period ( 28 days: $6.00 \mathrm{ppm}$ of $\mathrm{Zn}$ ). The percentage change in small lymphocytes was $20.4 \%$ in 21 days exposure period in Group D, while in case of large lymphocytes the percentage change was maximum $26.4 \%$ in Group D during 28 days exposure period in all the treated groups ( Table-1; Graph 2). The neutrophils increased significantly in all treated groups. The maximum numbers of neutrophils were $27 \%$ in groups $B$ and $D$ during 28 days exposure. Maximum percentage changes were $80.0 \%$ during 28 days exposure period in Group B and Group D and minimum changes were (13.3\%) during 7 days exposure period in Group B (Table-1;Graph-3). The maximum value of monocytes was recorded during 14 days exposure in Group $C$ and 21 days (Group D) with maximum changes of $133.3 \%$ (Table-1;Graph-4). The changes in eosinophils were highest (100.0\%)at $6.00 \mathrm{ppm}$ Zn during 21 days $\& 28$ days exposure period (Table$1 ;$ Graph-5). Finally, the highest value of basophils was $2 \%$ with $100 \%$ changes in GroupD during 21 days exposure period (Table-1;Graph-6). 


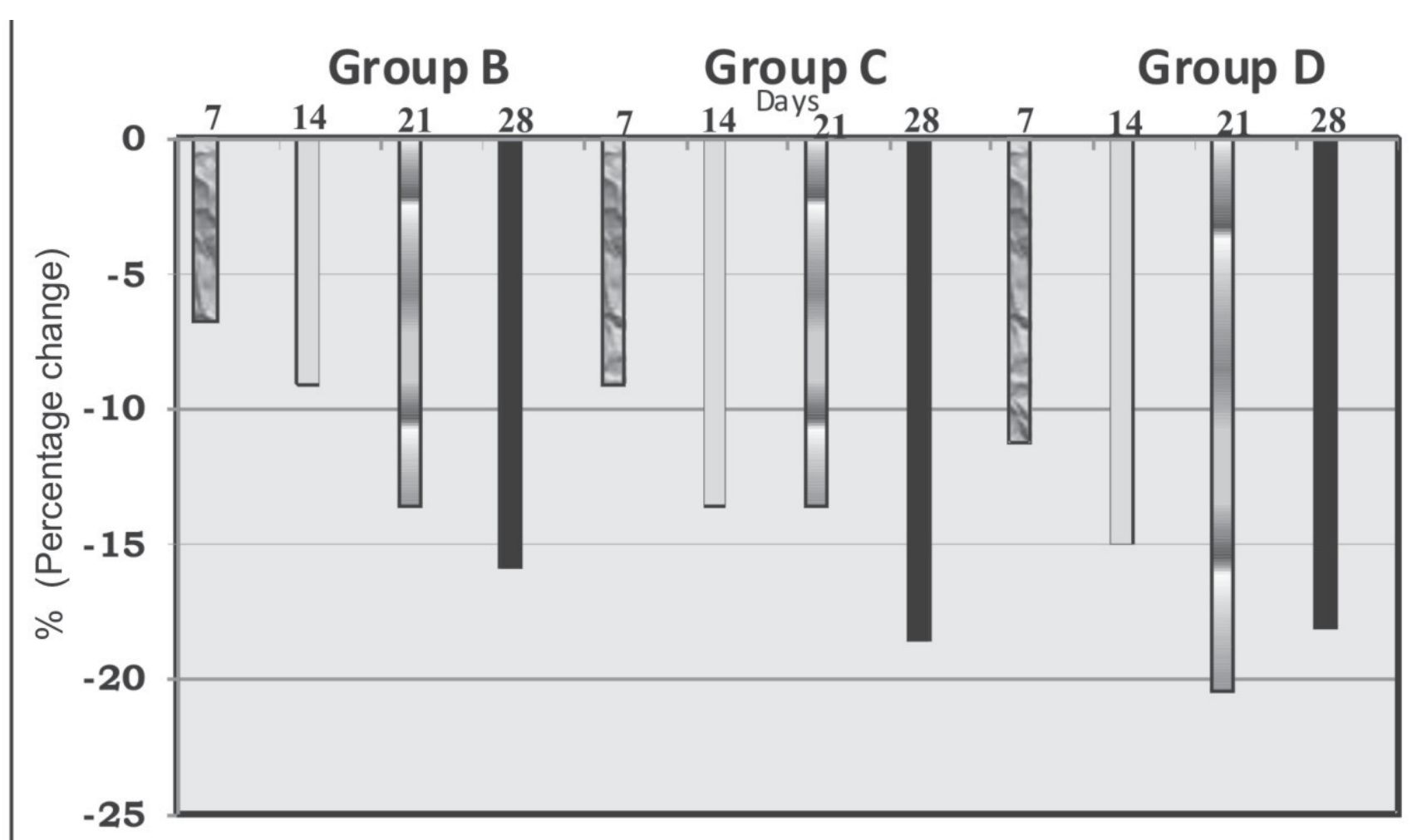

Fig. 1: Percentage change in small lymphocytes counts of $C$. batrachus to various concentrations of $\mathrm{Zn}$

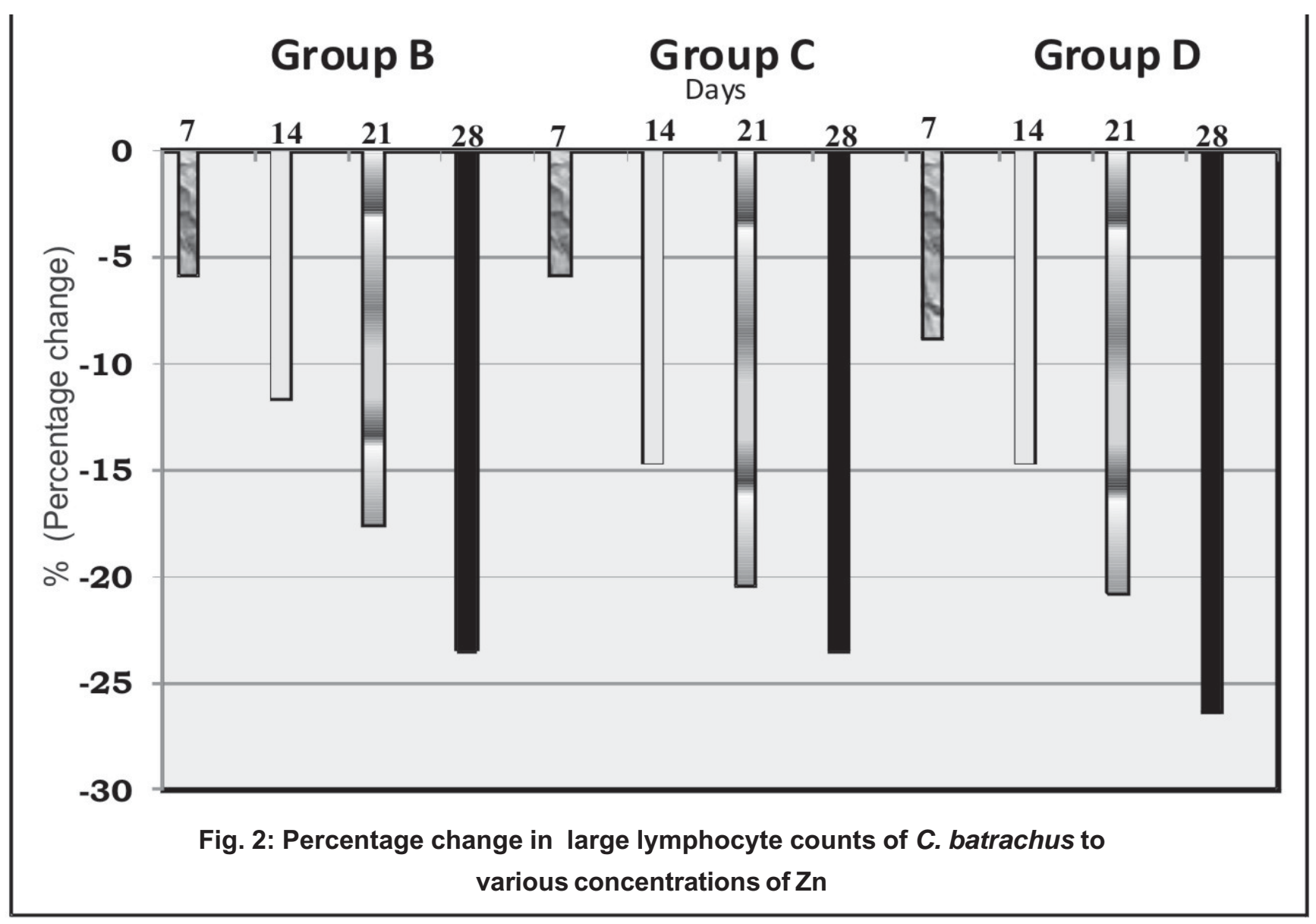




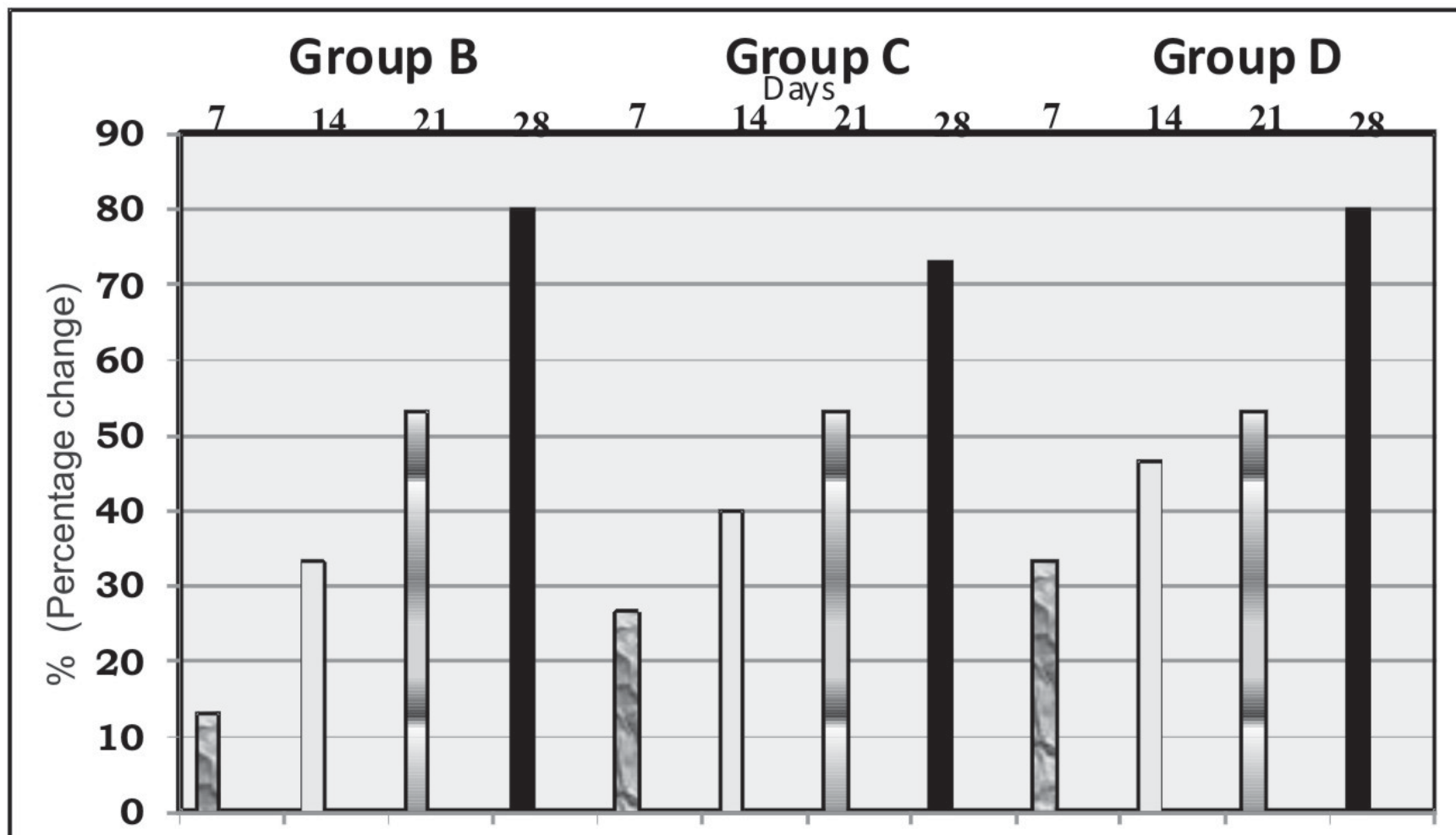

Fig. 3: Percentage change in neutrophils counts of $C$. batrachus to various concentrations of $\mathrm{Zn}$

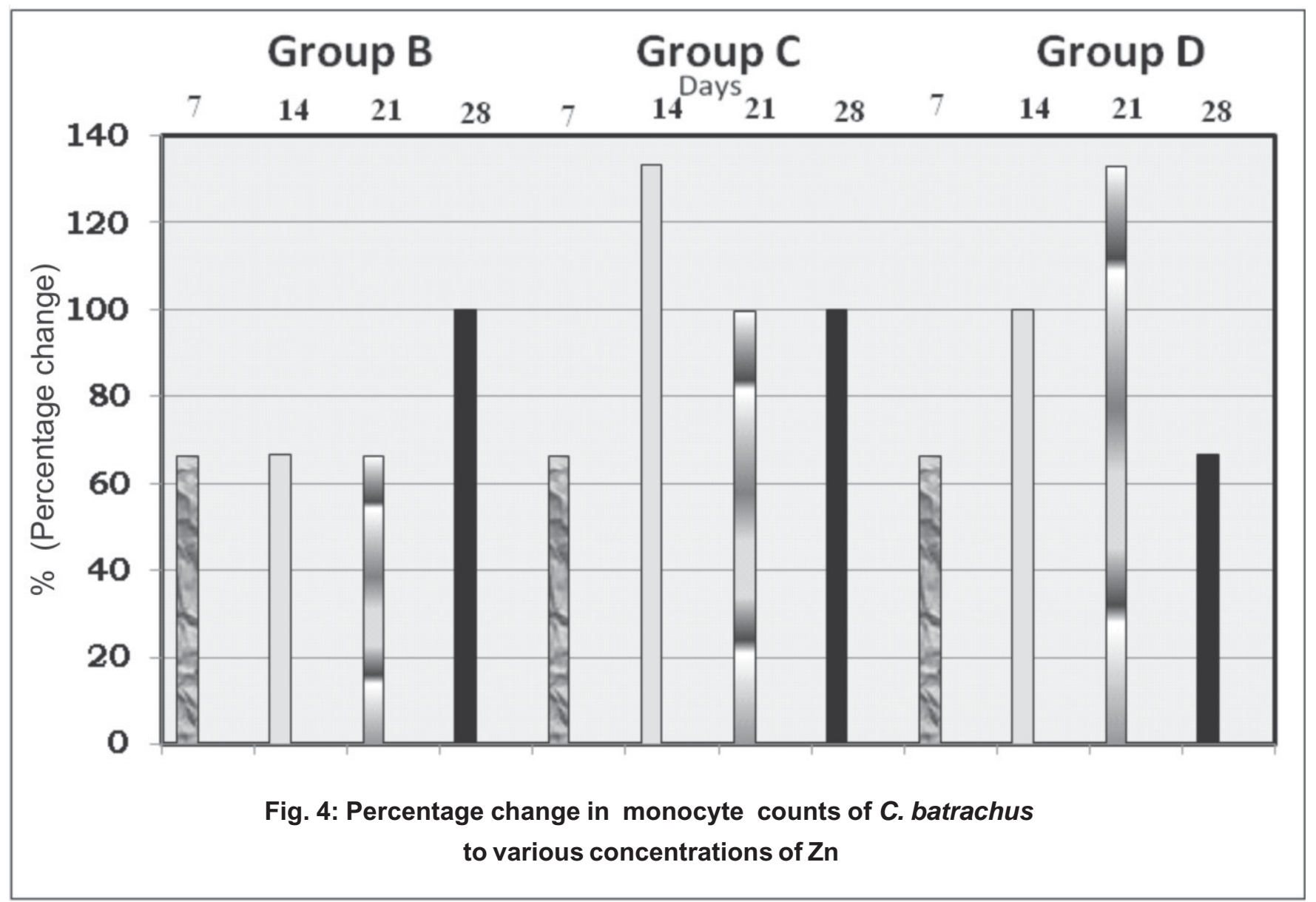



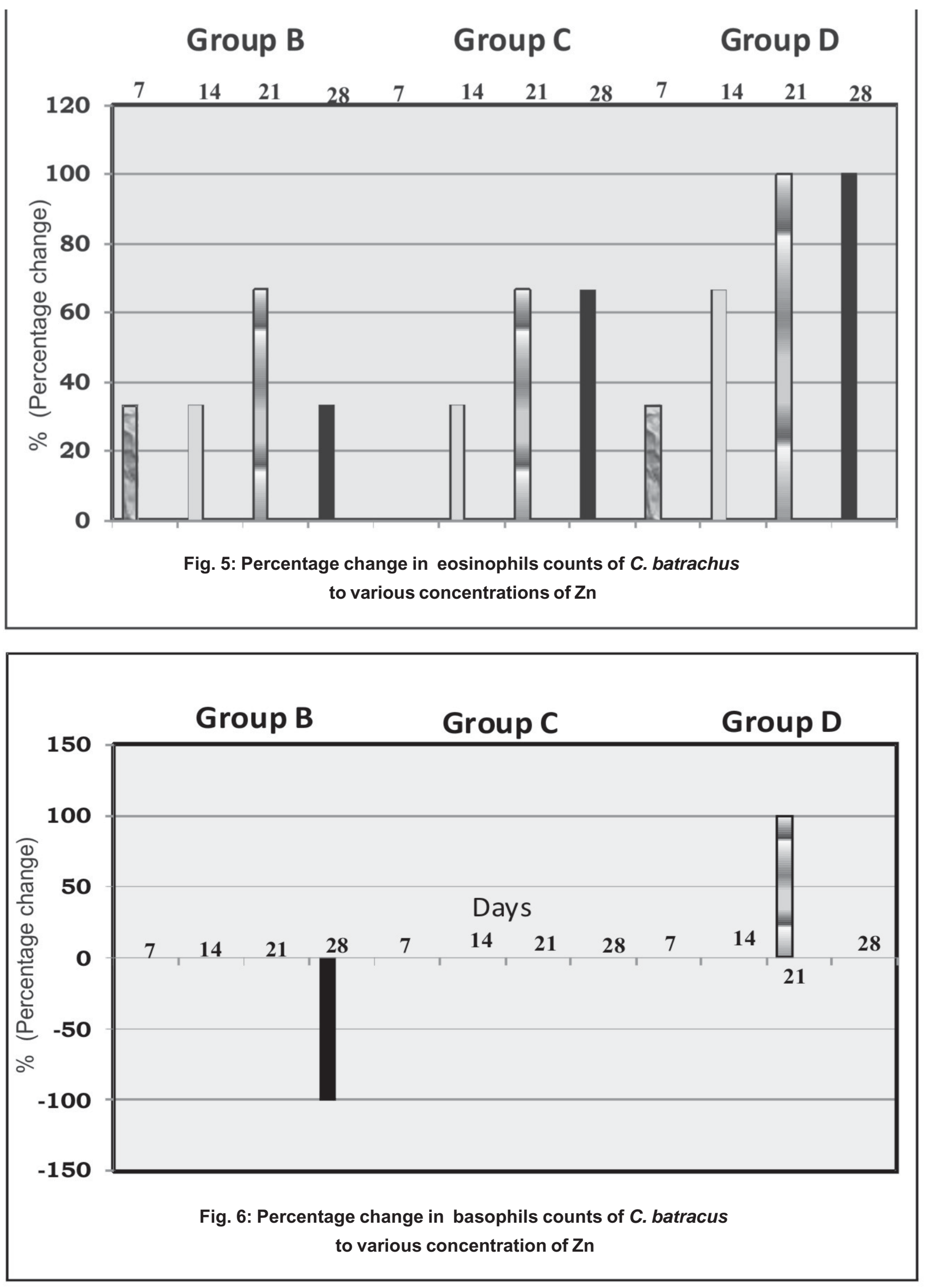


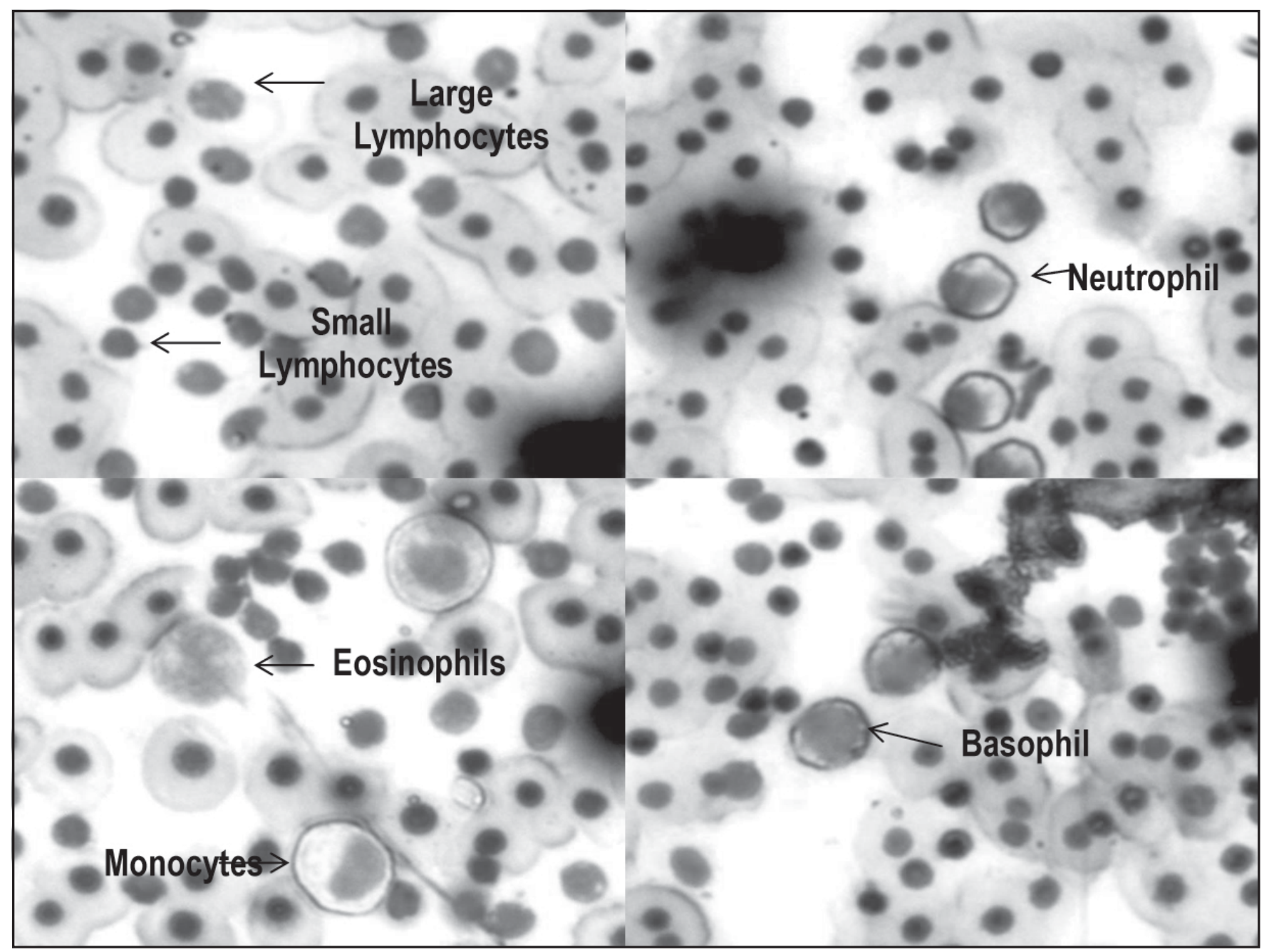

Fig. 7 : Differential leucocytes of C. batrachus exposed to Zn

\section{Discussion}

Zinc is the second most abundant trace element after iron. It is an essential element and micronutrient in living organism found almost in every cell and is involved in biochemical activities ${ }^{22}$. It is well established that $\mathrm{Zn}$ is vital for the growth and development of fresh water animals in certain amount but excess concentration directly through water or food chain is harmful and toxic ${ }^{10,11}$. Additionally, zinc is involved in more complicated functions, such as the immune system, neurotransmission and cell signaling ${ }^{4,10}$. WBC plays a major role in the defense mechanism of the fish. It consists of granulocytes, mononcytes lymphocytes and thrombocytes. The immune system of different fish species has been studied.Granulocytes and monocytes function as phagocytes to salvage debris from injured tissues and lymphocytes produce antibodies ${ }^{9,15}$ Lymphocytes, neutrophils and moncytes are involved in the immune response ${ }^{2}$. Fish immune system getstriggered; as a result, WBC and DLC leave blood and enter the affected regions which is reflected in the number of cells ${ }^{24}$.

However, studies on the effects of heavy metal on immunological parameters are limited, generally both increase and decrease in the number of lymphocytes, eosinophils and thrombocytes. Lymphocytes percentage was lower than normal indicating lymphopenia and this can serve as a suitable marker of immune system defiency and xenobiotic substances treatment that can also decrease the body supply of lymphocytes ${ }^{3}$.

In our study, we have tried to investigate the influence of different concentrations of zinc on the differential leucocytes of $C$. batrachus.A significant drop in lymphocytes counts, reduced lymphocyte viability and the presence of abnormal cells indicated cytotoxic effects of zinc and reduction in the blood lymphocyte ${ }^{17}$. It has been reported that zinc reduced proliferation of common carp lymphocytes in vivo as well as in vitro ${ }^{13}$. Short term exposure of $\mathrm{Zn}$ and $\mathrm{Cd}$ induces a persistent stress, decreases lymphocytes, increases neutrophils counts 
which reduces the immune potential of common carp ${ }^{28}$ while zinc induced insignificant decrease in the percentage of basophils, eosinophils and thrombocytes and sharp increase in lymphocytes of Heteroclarias ${ }^{14}$.

The immunological parameters in $\mathrm{Cd}$ exposed Clarias gariepinus resulted in decreased lymphocytes and eosinophils while neutrophils and monocytes counts increased apparently corresponding to specific immune functions ${ }^{8}$. On the other hand due to zinc exposure, the fishes were able to stimulate their immune system in order to overcome zinc mediated stress by showing increase in TLC in blood ${ }^{24}$. The authors also mentioned that amongst DLC, Iymphocytes are the major contributors towards the increase/ decrease of TLC because zinc treated fishes may also release more lymphocytes and monocytes and suppress neutrophils. Eosinophils and basophils were not affected significantly. When Caspian roach (Rutilus caspicus) was exposed to $\mathrm{LC}_{10}$ and $\mathrm{LC}_{50}$ zinc concentration, the lymphocytes and monocytes decreased and neutrophils and eosinophils decreased.Zinc is essential for growth but in higher concentration, it can be harmful and suppresses the immune system ${ }^{12}$.Significant differences in DLC between control and $\mathrm{Zn}$ exposed groups were observed in Abramisbrama juveniles ${ }^{26}$. CuO nanoparticles significantly change DLC after acute and chronic exposure and result in lethal changes in lymphocytes, neutrophils, monocytes and basophils ${ }^{13}$. The consequential results of this study are that zinc in high amount may cause alterations in the immunological parameters of the investigated fish.

\section{References}

1. Ahmad Z, Butt MS, Hussain R, Ahmed A, Riaz, M. Effect of oral application of xylanase on some hematological and serum biochemical parameters in broilers. Pak. Vet. J. 2013;33: 388-390.

2. Al-Bairuty GA, Shaw BJ, Handy RD, Henry TB. Histopathological effects of water borne copper nanoparticles and copper sulphate on the organs of rainbow trout (Oncorhynchus mykiss). Aquat. Toxicol. 2013; 126: 104-115.

3. Banaee M, Mirvagefei AR, Rafei GR,MajaziAmiri B.Effect of sub-lethal diazinon concentration on blood plasma biochemistry. Int. J. Env. Res. 2008; 2 (2): 189-198.

4. Celik U, Oehlenschläger J. Determination of zinc and copper in fish samples collected from Northeast Atlantic by DPSAV. Food Chem 2004; 87: 343-347.

5. Devi P, Baruah, D,Baruah BK, Borkotoki A. Impact of endosulphanon some haematological parameters of Channa punctatus (Bloch). Poll. Res. 2008 ;27, (3):485-488.

6. Eide DJ, Zinc transporters and the cellular trafficking of zinc. Biochim. Biophys. Acta 2006; 1763: 711-722.

7. Elaiyaraja C, Subha A, Kumari S, Arunachalam A. Effects of zinc sulphate on the biochemical changes in the fish Cyprinuscarpio. Int. J. Zool. Appl. Biosci. 2018;3 (5):390-395.

8. El-Boshy M, El-Ashram A, Risha E, Abdelhamid F, Zahran E, Gab-Alla A.Dietary fucoidan enhance the nonspecific immune response and disease resistance in African catfish, Clarias gariepinus, immuno suppressed by cadmium chloride.Vet.Immunol.Immunopathol. 2014;162(3-4):168-173.

9. Ellis AE. Innate host defense mechanisms of fish against viruses and bacteria. Dev. Comp. Immunol.2001; 25: 827-839.

10. Hao L, Chen L, HaoJ, Zhong N. Bioaccumulation and subacute toxicity of zinc oxide nanoparticles in juvenile carp (Cyprinuscarpio): a comparative study with its bulk counterparts. Ecotoxicol. Environ. Saf. 2013; 91: 52-60.

11. Hayat S, Javed M, Razzaq S. Growth performance of metal stressed major carps viz. Catlacatla, Labeo rohita and Cirrhinus mrigala reared under semi-intensive culture system. Pak. Vet. J.2007; 27: 8-12.

12. Hedayati A, Rezaei H,Darabitabar F. Environmental Impact of zinc on hematological, biochemical and immunological parameters in Caspian Roach (Rutilus caspicus). Iran. J. Energ. Env. 2016; 7(4): 382-386.

13. Kaviani EF, Naeemi AS,Salehzadeh A. Influence of copper oxide nanoparticle on hematology and plasma biochemistry of caspian trout (Salmo truttacaspius) following acute and chronic exposure. Pollution 2019; 5(1) : 225-234.

14. Kori-Siakpere $\mathrm{O}$, Oghoghene UE.Sublethalhaematological effects of zinc on the freshwater fish, Hetero clarias sp. (Osteichthyes: Clariidae)African J. Biotechnol.2008; 7 (12): 2068-2073. 
15. Maheswaran R, Devapanl A, Muralidharan S, Velmurugan B, Ignaeimuthu S. Haematological studies of fresh water fish, Clarias batradrus (L) exposed to mercuric chloride. Int. J. Integrat. Biol. 2008; 2(1), 49-54.

16. Maret W,Krezel A. Cellular zinc and redox buffering capacity of metallothionein/thionein in health and disease. Mol. Med.2007; 13: 371-375.

17. Mishra S,Srivastava AK.Hematology as index of sublethal toxicity of zinc in a freshwater teleost. Bull.Env. Cont.Toxicol.1979; 22: 695-698.

18. Ololade IA,Ogini O, Behavioural and hematological effects of zinc on African catfish, Clarias gariepinus. Int. J. Fish. Aquat. 2009; 1:22-27.

19. Raina S, Sachar A. Effect of heavy metal, zinc and carbamate pesticide, sevin on haematological parameters of fish, Labeoboga.Int. J. Innov. Res. Sci. Eng. Technol. 2014; 3(5):12636-12644.

20. Sachar A, Raina S. Haematological alterations induced by lindane in a fish, Aspido pariamorar.Global J. Biol. Agri. Health Sci.2014; 3 (1): 38-42.

21. Saxena M, Saxena H, Kaur P, Kaur K.Effect of heavy metal pollution of water on response of fish lymphocytes to mitogenic stimulation. Internet J. Vet. Med. 2009;5(2):1-4.

22. Sfakianakis DG, Renieri E, Kentouri M, Tsatsakis AM. Effect of heavy metals on fish larvae deformities: A review. Env. Res.2015; 137: 246-255.

23. Shuilleabhain SN, Mothersill C, Sheehan D, O‘Brien NM, Halloran JO, Van Pelt FNAM, Davoren M. In vitro cytotoxicity testing of three zinc metal salts using established fish cell lines. Toxicol. in vitro. 2004; 18:365-376.

24. Suganthi P, Mural IM, Sadiq BA, Syed Mohamed HE, Basu H, Singhal, RK. Haematological studies on freshwater Tilapia treated with ZnO nanoparticles. J. Adv. Appl. Scient. Res. 2015; 1(1): 41-67.

25. Tyagi A, Srivastava N.Haematoloical changes of fishChanna punctatus (Bloch) to chronic zinc exposure. J. Env. Biol.2005; 26 (2): 429-432.

26. Vahdatiraad L, Yazdanparastlangroodi M.Alteration in haematological indices in Abramis brama juveniles induced by sublethal concentration of zinc.Int. J. Inn. Res. Adv. Stud. (IJIRAS) 2017; 4 (5):65-69.

27. Wintrobe MM. In: Clinical haematology. VIII Ed. Lea and Febiger. Philaldelphia1981: 202.

28. Witeska M, Kosciuk B.The changes in common carp blood after short-term zinc exposure. Env. Sci. Poll. Res. 2003;10:284-286.

29. Witeska M. Stress in fish hematological and immunological effects of heavy metals. Electronic J. Ichthyol. 2005; 1:35-41. 